\title{
Host range expansion may provide enemy free space for the highly invasive emerald ash borer
}

\author{
David G. Olson • Lynne K. Rieske
}

Received: 21 March 2018/ Accepted: 20 September 2018/Published online: 25 September 2018

(C) The Author(s) 2018

\begin{abstract}
Emerald ash borer, Agrilus planipennis Fairmaire (Coleoptera: Buprestidae), is an aggressive invader from Asia that has killed millions of trees in North America, causing substantial ecosystem effects and economic losses. All North American ash, Fraxinus spp., are thought to be susceptible, but recently emerald ash borer has been documented developing in a novel host, white fringetree, Chionanthus virginicus. We evaluated larval performance in two common ash species and white fringetree by infesting bolts with emerald ash borer eggs. In addition we evaluated cambial nitrogen, carbon, carbon:nitrogen, stem density, and response to artificial wounding, to determine which host plant characteristics most influence larval development. We also conducted choice and no choice assays using the classical biological control agent, Tetrastichus planipennisi Yang (Hymenoptera: Eulophidae), to assess its ability to locate larval emerald ash borer in the different host plants. We found significantly lower survival rates of emerald ash borer larvae in white fringetree compared to white ash, F. americana. Larval phloem consumption and larval growth were lower in fringetree than in either white or blue ash, F. quadrangulata. Carbon content and
\end{abstract}

D. G. Olson · L. K. Rieske ( $₫)$

Department of Entomology, University of Kentucky, S-

$225 \mathrm{Ag}$ North, Lexington, KY 40546, USA

e-mail: olsondgm@gmail.com

L. K. Rieske

e-mail: Lrieske@uky.edu density were greater in fringetree than in either ash species. Response to wounding, measured by callus tissue formation, was greatest in white ash. In choice assays, T. planipennisi only parasitized emerald ash borer larvae in ash bolts, and in no-choice tests failed to parasitize larvae in fringetree. Our findings corroborate studies showing that fringetree is a suitable host for emerald ash borer larvae. Failure of $T$. planipennisi to parasitize larvae within fringetree has implications for the efficacy of this classical biological control agent in regulating emerald ash borer populations. Coupled with the use of white fringetree as a reservoir host, the enemy free space provided to emerald ash borer through use of this alternate host may have significant repercussions for emerald ash borer invasion dynamics.

Keywords Agrilus planipennis - Biological control · Enemy free space $\cdot$ Host shift - Tetrastichus .

Chionanthus

\section{Introduction}

Both biotic and abiotic constraints serve to structure ecological communities (Strong et al. 1984; Verhoef and Morin 2010). These constraints affect geographic distributions (Davis et al. 1986; Huston and DeAngelis 1994; Meier et al. 2010), resource availability (Huston and DeAngelis 1994; Davis et al. 2000), competitive 
interactions (Huston 1997; Davis et al. 2005), and also influence trophic relations (Jeffries and Lawton 1984; Hunter and Price 1992; Stamp 2001; Wisz et al. 2013). Fluctuating resources and natural enemies both influence invasiveness and have emerged as prominent hypotheses in invasion ecology. Freed from the constraints of population regulation imposed by limited resources (Davis et al. 2000; Davis and Pelsor 2001) and natural enemies (Jeffries and Lawton 1984), invading organisms are subsequently able to persist in, or even increase, their geographic range. In contrast, the abiotic constraints dictating community structure and acting on a newly arriving non-native species are often similar between donor and recipient regions (Elton 1958; Ruiz et al. 2000; Richardson and Pyšek 2006). Host range expansion or host switching is one mechanism that may allow introduced organisms to overcome these abiotic constraints. Host range expansion can buffer the depletion of optimal host material (Sax et al. 2007) and contribute to enemy free space (Gratton and Welter 1999; Drake 2003; Murphy 2004), ultimately leading to increases in population growth and potentially to geographic range expansion (Crowl et al. 2008).

Since its introduction to North America in the mid1990s (Haack et al. 2002; Siegert et al. 2014), emerald ash borer (Agrilus planiplennis Fairmaire, EAB) has established in much of the eastern portion of the United States, and has invaded several states west of the Mississippi River (Herms and McCullough 2014; USDA APHIS MAP 2018), causing extensive mortality and loss of ash (Fraxinus spp.). The ash borer larva develops underneath the bark of the host, consuming cambial tissue before pupating and emerging as an adult (Cappaert et al. 2005). Ash species native to eastern North America show little to no resistance to the borer (Rebek et al. 2008), and endemic natural enemies are unable to sufficiently curtail population growth (Duan et al. 2009, 2012). As a result, EAB infestation leads to ash mortality in 1-4 years by effectively girdling the tree (Rebek et al. 2008; Klooster et al. 2014). Invasion by EAB has led to a widespread loss of native ash species in urban and wildland forests, altering forest composition and structure (Flower et al. 2013; Levin-Nielsen and Rieske 2015; Klooster et al. 2014), affecting native biodiversity (Lindell et al. 2008; Gandhi and Herms 2010; Perry and Herms 2016) and trophic relationships (Duan et al. 2012; Davidson and Rieske 2015; Savage and Rieske 2018). Widespread ash mortality impacts management plans (Looney et al. 2017) and restoration efforts (Burr and McCullough 2014), and causes extraordinary economic losses (Klooster et al. 2014; Herms and McCullough 2014).

Systemic insecticides can kill EAB (Smitley et al. 2010), but the prevalence and extent of ash in urban and wildland forests makes this management approach impractical. Because native parasitoids are unable to effectively suppress EAB, a concerted effort was made to identify classical biological control agents for importation to help regulate populations (Liu et al. 2003). Of those classical biological control agents, Tetrastichus planipennisi (Hymenoptera: Eulophidae) has been the most effective at establishing and dispersing from release sites (Duan et al. 2011; Jennings et al. 2016). Tens of thousands of $T$. planipennisi have been released for EAB management in central Kentucky forests and urban areas (Davidson and Rieske 2016; Graziosi and Rieske 2017). Host finding by $T$. planipennisi appears reliant on vibrational cues (Ulyshen et al. 2011; Chen et al. 2015), whereas olfactory cues appear less important (Chen et al. 2015). But the effectiveness of T. planipennisi in regulating $\mathrm{EAB}$ populations is limited by its short ovipositor and inability to penetrate thick bark of larger trees (Abell et al. 2012), and an apparent phenological asynchrony in portions of EAB's invaded range (Duan et al. 2014, 2015).

Host range studies following EAB's initial discovery suggested that all North American ash species were susceptible, and that EAB development in North America would be confined to Fraxinus species (Anulewicz et al. 2008; Rebek et al. 2008; Lyons et al. 2009). Although North American blue ash ( $F$. quadrangulata) appears to possess some resistance (Tanis and McCullough 2012; Spei and Kashian 2017), it lacks the level of resistance found in Manchurian ash ( $F$. mandshurica), the co-evolved ancestral host of EAB (Whitehill et al. 2012; Peterson et al. 2015). In the initial host range studies, other common members of the Oleaceae were evaluated, deemed unsuitable, and determined to be of no concern in the invasion dynamics of EAB in North America (Anulewicz et al. 2008; Lyons et al. 2009).

Surprisingly, in 2015 EAB was reported completing its development on another Oleaceous host, white fringetree (Chionanthus virginicus), in south-central Ohio (Cipollini 2015). Utilization of this novel host 
appears to have co-occurred with the initial EAB invasion in central Ohio (Thiemann et al. 2016) but went unnoticed. Following the initial detection of $\mathrm{EAB}$ in white fringetree in Ohio, EAB was soon discovered on fringetree in other areas including Lexington, KY. In spring of 2016 an adult beetle was recovered emerging from plant material collected in fall 2015 on the University of Kentucky campus.

White fringetree is a small tree or shrub with showy white flowers, native to the southeastern United States (Missouri Botanical Garden 2017). Horticultural varieties are widely planted as ornamentals throughout much of the range of North American Fraxinus, and in many areas where EAB has already invaded (USDA APHIS Map 2018). Interestingly, C. retusus, an Asian congeneric of $C$. virginicus that shares an ancestral native range with $\mathrm{EAB}$, is resistant to the beetle (Cipollini and Rigsby 2015).

Cipollini and Rigsby (2015) determined that EAB is able to complete its life cycle from egg to adult on white fringetree. However, a full understanding of how this novel host impacts EAB development, how the novel host will affect efficacy of biological control agents, and what the consequences will be for EAB invasion dynamics in North America is lacking. Therefore, we compared host utilization by EAB of two common ash species, white and blue, F. americana and $F$. quadrangulata, respectively, with white fringetree, and evaluated plant characteristics that could contribute to differences in host suitability (Bernays and Chapman1994). Secondly, we evaluated the ability of $T$. planipennisi to locate and utilize EAB within white fringetree, and further evaluated parasitoid responses to olfactory and visual stimuli associated with both ash and fringetree. Because $T$. planipennisi is reliant primarily on vibrational cues to locate its EAB host within infested ash (Ulyshen et al. 2011), we hypothesized that the novel host plant would compromise EAB location by $T$. planipennisi and contribute to enemy free space for EAB populations, with potential consequences for the $\mathrm{EAB}$ invasion.

\section{Methods}

\section{EAB development}

Two stems of white ash, two of blue ash, and four of white fringetree were harvested on June 21, 2016 from trees in Fayette Co. KY for bioassays to compare EAB larval survival, growth, and cambial tissue consumption. Upon removal, stems were placed immediately in tap water to limit desiccation, and in the laboratory they were sectioned into $30 \mathrm{~cm}$ lengths and labeled. Stems with signs of emerald ash borer or other damage were discarded. Since stems varied in diameter $(2-5 \mathrm{~cm})$ both within and between species, bolts of each species were grouped into large $(>3.5 \mathrm{~cm})$ and small $(\leq 3.5 \mathrm{~cm})$ size classes.

Twenty-four hours later, five EAB eggs attached to pieces of paper coffee filters (Kroger, Cincinnati $\mathrm{OH}$ ) were evenly spaced along the length of each experimental bolt approximately $5 \mathrm{~cm}$ from one end, and secured using $2.5 \mathrm{~cm}$ wide strips of parafilm (Bernis NA, Neenah, WI) (Duan et al. 2013a, b). One comparably sized bolt of each species (white ash, blue ash, and white fringetree) infested with five EAB eggs was randomly selected and placed in $4 \mathrm{~cm}$ of sand moistened with tap water in $13.5 \times 13.5 \times 30 \mathrm{~cm}$ transparent plastic containers (OXO, NY, NY) and covered with fine mesh secured by a rubber band. There was one bolt of each species infested with five EAB eggs in each container, for a total of 39 bolts in 13 containers $(\mathrm{N}=195$ eggs). Assay containers were maintained in a growth chamber at $25{ }^{\circ} \mathrm{C}$ and 15:9 L:D.

After 6 weeks, each bolt was carefully debarked using a knife and the fate of each individual EAB larva was recorded. All living EAB larvae were collected and aged by measuring head capsule width (Wang et al. 2005). Larval galleries were measured by wrapping each experimental bolt in translucent plastic and tracing over the galleries with a black marker. Gallery tracings were digitally photographed and ImageJ (Rasband NIH 1997-2016) software was used to calculate the total area of cambial tissue consumed on each bolt.

\section{Host plant characteristics}

Host characteristics that may affect host suitability for EAB were assessed by evaluating nitrogen and carbon 
content of the cambium. For nitrogen and carbon analysis, three samples were collected from six trees of white ash and fringetree, and four trees of blue ash using a $10 \mathrm{~mm}$ cork borer to penetrate through the bark, removing a plug of tissue. Bark was removed from sample plugs using a razor blade, leaving only cambial tissue which was then weighed, dried at $40{ }^{\circ} \mathrm{C}$ for 3 days, and analyzed using a combustion assay (Flash Elemental Analyzer 1112 Thermo Fisher Scientific Inc., Waltham, MA).

We also assessed plant characteristics that may affect parasite host location, focusing on those that are most likely to influence vibratory cues thought to be relevant to $T$. planipennisi (Ulyshen et al. 2011). To evaluate wood density $\left(\right.$ density $=$ mass $\cdot$ volume $^{-1}$ ), four stems of similar diameter of each species were sectioned into $3 \mathrm{~cm}$ pieces. To quantify the volume of each $3 \mathrm{~cm}$ section ( $\mathrm{N}=12$ per species), the amount of water displaced in a $100 \mathrm{~mL}$ beaker per section was used to determine total volume using Archimedes Principle $\left(\mathrm{V}_{\text {object }}=\right.$ mass of water displaced, given Density $\left._{\mathrm{H} 2 \mathrm{O}}=1.0\right)$. Samples were dried at $45{ }^{\circ} \mathrm{C}$ for $24 \mathrm{~h}$. Mass was then measured (Mettler Toledo AB204) and divided by volume to calculate density for each stem section.

\section{Host plant response to wounding}

Host response to wounding in situ was simulated by measuring callus tissue formation following mechanical wounding using a $1 \mathrm{~cm}$ diameter cork borer and hammer (Dunn et al. 1990). Six stems of white ash and fringetree, and four of blue ash were selected at sites in Fayette Co., KY, and three wounds were made through the bark and into the cambial and phloem tissues at a height of $1 \mathrm{~m}$ around the stem circumference, separated by $120^{\circ}$. Wounds were then digitally photographed with a 12-megapixel camera at a distance of $10 \mathrm{~cm}$ at 4 week intervals from April through October to document the size of the open wound and the amount of callus tissue formed. Photographs of the wounds and associated callus tissue formation were quantified using ImageJ (Rasband NIH 1997-2016), and compared within and between plant species.
Host plant effects on a classical biological control agent

Choice test: Bolts of white ash, blue ash, and white fringetree similar in diameter were infested with $E A B$ as described above under 'EAB Development,' and one bolt of each species were placed in $13.5 \times 13.5 \times 30 \mathrm{~cm}$ assay containers $(\mathrm{N}=6)$. After 5 weeks in a growth chamber at $25^{\circ} \mathrm{C}$ and 15:9 L:D to allow for adequate EAB larval development, four mated female $T$. planipennisi were introduced into each assay container, which were placed in a growth chamber at $25{ }^{\circ} \mathrm{C}$ and 14:10 L:D. After 6 days, the wasps were removed and bolts were held at $25{ }^{\circ} \mathrm{C}$ for an additional 21 days to allow for maturation of parasitoid larvae. The bolts were then debarked to quantify parasitization, and all intact larvae of EAB were measured.

No-choice test: Nine white fringetree were located in Lexington $\mathrm{KY}$, and three stems of each were inoculated with eight EAB eggs as described above. In the field, eggs were covered with fine mesh secured with duct tape to prevent predation. After 6 weeks to allow EAB egg hatch and larval development, cages of fine mesh were built around each intact, infested stem, and two mated female $T$. planipennisi were introduced. Females were fed a diluted honey mixture every $\sim 48 \mathrm{~h}$. Assays were monitored for 21 days, after which the stems were cut and surviving female wasps were collected. Stems were debarked, larvae measured, and all mortality of larvae recorded.

Responses to olfactory and visual cues

Olfactory and visually-mediated responses of $T$. planipennisi were evaluated using a glass Y-tube olfactometer approximately $27 \mathrm{~cm}$ in length with a $2.25 \mathrm{~cm}$ diameter central stem and $2.5 \mathrm{~cm}$ diameter arms, in combination with excised plant material and EAB larvae (Graziosi and Rieske 2013). Air was pumped through activated charcoal, a HEPA-CAP 36 microfiber filter (Whatman: Clifton NJ, USA), and deionized water at a rate of $0.05 \mathrm{~L} / \mathrm{Min}$, before being introduced to the odor sources. The Y-tube setup was contained in a box which minimized ambient light and provided a steady even light source from two $15 \mathrm{~W}$ fluorescent bulbs. Ambient temperature was raised to $27{ }^{\circ} \mathrm{C}$ with the inclusion of a heating pad $(\mathrm{K}+\mathrm{H}$ Manufacturing, Colorado Springs, CO). Female $T$. 
planipennisi were obtained from a USDA APHIS rearing facility via overnight shipment, then placed into transparent containers with honey until use. For each trial a naive $T$. planipennisi female was introduced to the system and allowed $10 \mathrm{~min}$ to make a choice by moving at least $3 \mathrm{~cm}$ up one arm; each completed set consisted of 20 female wasps that made a definitive choice. Used wasps were discarded after trials were completed and all trials were run between 0800 and $1700 \mathrm{~h}$ EDT from November 2017 to February 2018. Y-tubes were switched out after every trial and washed in acetone and dried completely before reuse. Wasps were introduced to the system via a central stem. Tissue samples and blanks within the system were also changed with respect to location on a regular basis.

The olfactory stimuli used were excised stem tissue from green ash, $F$. pennsylvanica, excised stem tissue from white fringetree, or EAB larvae that had been removed from white ash and rinsed in deionized water. All materials were collected in Lexington, KY on the morning of the assay. Each of these olfactory stimuli was evaluated against a blank in separate assays.

Visual stimuli consisted of ash leaves collected daily from greenhouse-grown green or tropical ash ( $F$. uhdei). Visual stimuli were placed along the outside wall of the Y-tube so that they were in a clear line of site and visible from the central stem, but not visible from the opposite arm, which contained no scent cues.

Olfactory stimuli of excised ash and fringetree stems were combined with the visual stimuli of ash leaves against a blank. Due to limitations in tissue availability, tropical ash leaves were combined with green ash, and a separate assay combined the visual cue with fringetree tissue. A trial was considered complete when 20 female wasps had made a choice.

\section{Statistical analyses}

Emerald ash borer egg hatch, larval survival, larval development (as measured by head capsule width), and EAB host utilization (cambium consumption) were evaluated using a 1-way randomized analysis of variance (Proc GLMMIX, SAS 9.3) to assess the effects of host plant (white ash, blue ash, white fringetree), tree, and bolt. When significant, a TukeyKramer test was used to evaluate differences among means.
To evaluate cambial carbon and nitrogen content and stem density as measures of host suitability among tree species, the mean of three values was calculated for each tree and a one-way ANOVA was performed to evaluate differences. A Tukey-Kramer test was performed to evaluate differences between means. Host plant response to wounding was analyzed by comparing wounds and callus tissue formation over time, and examining simple effects of species at each time point. Tukey-Kramer tests were employed for multiple comparisons. Because EAB parasitization in both the choice and no-choice assays was low, rates were not evaluated statistically. Parasitoid responses to olfactory and visual stimuli were assessed using a Chi squared analysis, assuming an expected outcome of $50 \%$ for each choice.

\section{Results}

EAB egg hatch was approximately $60 \%$ and did not differ between the three tree species (white ash $=$ $61.5 \pm 4.8$; blue ash $=56.9 \pm 5.5$; fringetree $=63.1 \pm 3.8$ ). However, larval survival was greatest on white ash and lowest on fringetree; blue ash was intermediate and did not differ between the two (Fig. 1a). Larval growth, as measured by head capsule width, was greater for EAB reared from Fraxinus compared to those reared from Chionanthus, but there was no difference in larval growth between the two ash species (Fig. 1b). Similarly, cambium consumption was lowest for EAB reared on Chionanthus (Fig. 2) but the ash species did not differ from one another.

Carbon content in the cambium differed among the three tree species, and was highest in fringetree and lowest in blue ash (Table 1), but neither nitrogen or $\mathrm{C}: \mathrm{N}$ differed among the three. Wood density was also highest in fringetree (Table 1), with no difference between the two ash species.

There was no difference among the three species in their responses to wounding, as measured by callus tissue formation, 4 weeks following the wounding event (Fig. 3). However, the rate of callus tissue formation in blue ash and fringetree began increasing relative to white ash, and by week 8 callus tissue formation in white ash diverged significantly from that of blue ash and fringetree. Formation of callus tissue in white fringetree differed from white ash at 8, 12, and 
(a)

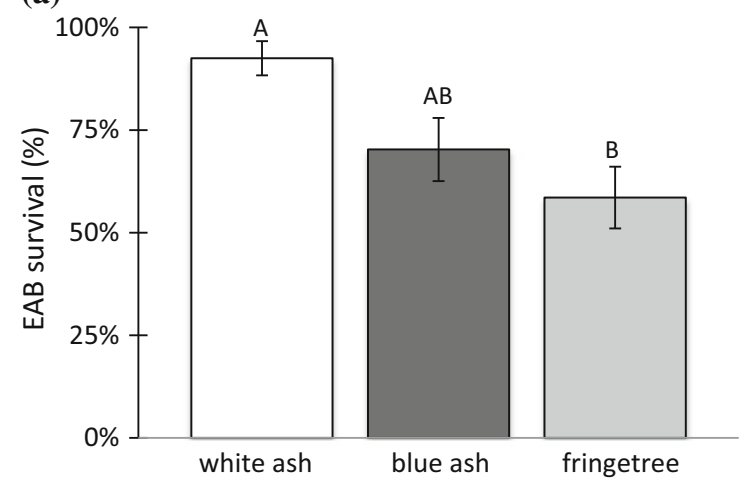

(b)

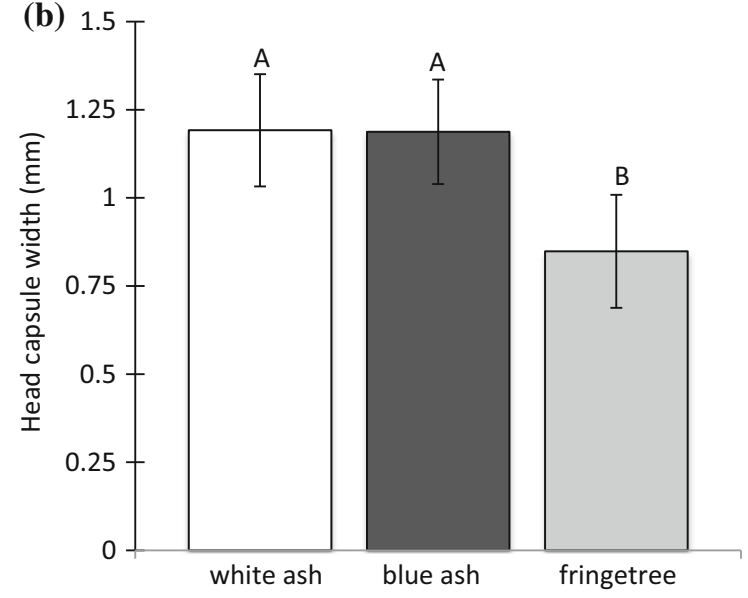

Fig. 1 Performance of emerald ash borer larvae after 35 days in bolts $(\mathrm{N}=13)$ of white ash, blue ash and fringetree artificially infested with emerald ash borer eggs, showing a survival $\left[\mathrm{F}_{1,34}=7.19, P<0.01\right]$ and $\mathbf{b}$ growth, as measured by head capsule width $\left[\mathrm{F}_{2,34}=10.20, P=0.0001, \mathrm{~N}=39\right]$. Means followed by the same letter do not differ $(\alpha=0.05)$

16 weeks, with blue ash values not significantly different from white fringetree.

In the choice assay with T. planipennis, $33 \%$ (6 of 18) of the bolts available with EAB larvae were parasitized. All EAB parasitization occurred in Fraxinus, with $80 \%$ occurring in blue ash, $20 \%$ in white ash, and none in white fringetree. In the no choice assay there were no signs of EAB parasitism in fringetree. Although EAB larval mortality was extremely high (85\%), all larvae recovered were at the critical 3rd or 4th instar, when they are highly susceptible to $T$. planipennisi parasitization (Duan et al. 2011). Regardless, the parasitization rate of EAB in white fringetree was zero.

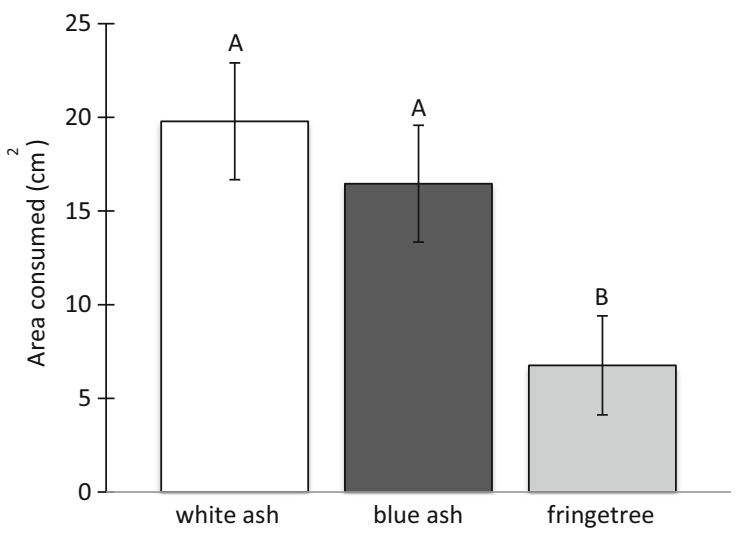

Fig. 2 Phloem consumption by emerald ash borer larvae in artificially infested bolts of white ash, blue ash, and fringetree $(\mathrm{N}=13)$ after 35 days $\left[\mathrm{F}_{2,22}=6.54, P<0.01\right]$. Means followed by the same letter do not differ $(\alpha=0.05)$

In our assessment of olfactory and visual responses, T. planipennisi females responded positively to ash tissue odor combined with an ash leaf visual cue, though the response was only weakly significant $(P=0.07)$. Tetrastichus planipennisi did not respond positively to ash tissue alone, the visual cue alone, an EAB larva, or fringetree tissue alone. Interestingly, a combination of fringetree odor with a visual cue of ash leaves yielded a strong preference for the blank control (Fig. 4), suggesting repellency.

\section{Discussion}

Adaptations to exploit additional host plants is just one mechanism whereby an insect herbivore can increase its invasibility. Host range expansion potentially increases the abundance and/or prevalence of available host material, which in turn increases the likelihood of geographic range expansion (Sax et al. 2007). An additional mechanism by which non-native organisms increase their invasiveness is by creating or exploiting enemy free space (Gratton and Welter 1999). The extent to which an increase in host options coupled with creation of enemy free space might influence the EAB invasion remains unknown.

We evaluated $E A B$ utilization of white fringetree in the context of its effectiveness as a larval host plant and to evaluate its influence on enemy free space, focusing on T. planipennisi, a central component of classical biological control efforts. We sought to more 
Table 1 Characteristics of white ash, blue ash, and white fringetree $(\mathrm{N}=16)$ evaluated for potential effects on developing emerald ash borer larvae

\begin{tabular}{lllll}
\hline Parameter & White ash & Blue ash & White fringetree & $\mathrm{F}_{\mathrm{df}} / P$ \\
\hline Carbon $(\%)$ & $40.2(16.4) \mathrm{b}$ & $38.9(19.5) \mathrm{c}$ & $42.9(17.5) \mathrm{a}$ & $\mathrm{F}_{2,15}=83.9 / 0.001$ \\
Nitrogen $(\%)$ & $0.43(0.19) \mathrm{a}$ & $0.50(0.25) \mathrm{a}$ & $0.50(0.20) \mathrm{a}$ & $\mathrm{F}_{2,15}=1.27 / 0.317$ \\
$\mathrm{C}: \mathrm{N}$ & $94.4(38.6) \mathrm{a}$ & $78.2(39.1) \mathrm{a}$ & $88.7(36.2) \mathrm{a}$ & $\mathrm{F}_{2,15}=3.89 / 0.210$ \\
Density $\left(\mathrm{g} / \mathrm{cm}^{3}\right)$ & $0.53(0.15) \mathrm{b}$ & $0.50(0.15) \mathrm{b}$ & $0.60(0.17) \mathrm{a}$ & $\mathrm{F}_{2,11}=9.10 / 0.002$ \\
\hline
\end{tabular}

Means (s.e.) within rows followed by the same letter do not differ $(\alpha<0.05)$

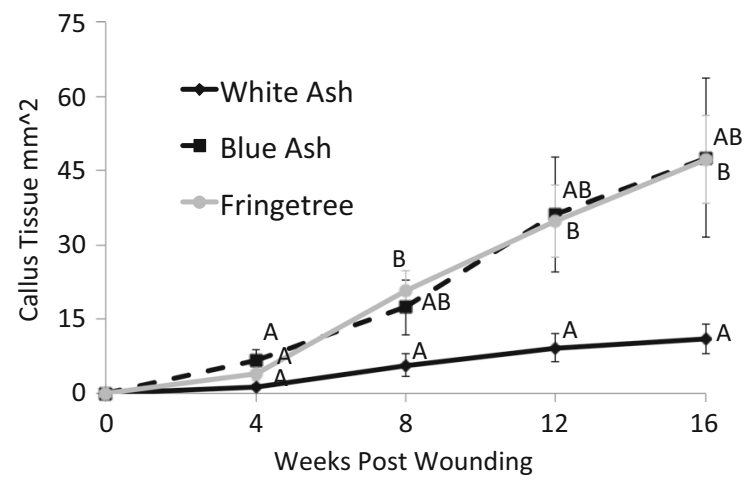

Fig. 3 Callus tissue formation after artificial wounding on white ash, blue ash, and white fringetree $(\mathrm{N}=12)$ at $4,8,12$ and 16 weeks. $\left[\mathrm{F}_{6,39}=8.77, P=0.001\right]$. Means followed by the same letter do not differ $(\alpha=0.05)$

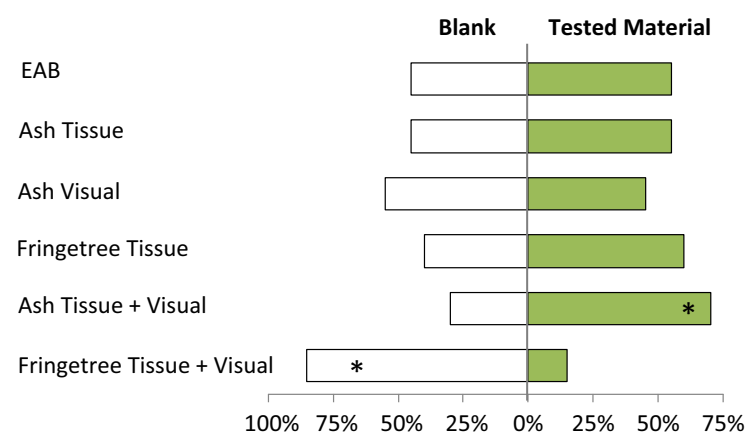

Fig. 4 Y-tube choice test results for T. planipennisi ( $\mathrm{N}=20$ for all trials). Ash tissue + visual cue: $P=0.07$; fringetree tissue + visual cue: $P=0.001$. * indicates significant difference at $\alpha=0.1$

fully understand the relationship between EAB and its novel white fringetree host, and to determine whether T. planipennisi can locate and utilize larval EAB developing in fringetree relative to those developing in ash hosts. Ultimately our goal is to evaluate how expansion of the host range through utilization of white fringetree may affect $\mathrm{EAB}$ invasion dynamics in eastern North America.

We found that $\mathrm{EAB}$ developing in white fringetree has lower survival, slower development (head capsule width), and lower consumption than EAB reared in Fraxinus hosts, corroborating similar studies (Cipollini and Rigsby 2015), and equate these findings to nutritional and physical attributes of the host plants. Insect growth is closely tied to the nitrogen content of host material (Mattson 1980). Our analyses of $\mathrm{N}$ and $\mathrm{C}: \mathrm{N}$ ratios from within cambial tissue suggest that nitrogen is unlikely to be contributing to the differences we observed in insect performance, since neither $\mathrm{N}$ or C:N levels differed among the three hosts tested.

Our analysis did demonstrate, however, that white fringetree contains higher levels of carbon in its cambial tissue, has greater stem density, and also has a more rapid response to wounding than does the highly preferred white ash, all of which could contribute to EAB's relatively poor performance in white fringetree. Higher overall stem density and a rapid response to wounding could potentially impede gallery formation and slow larval development. Studies on the closely related bronze birch borer, A. anxius Gory, a specialist on birch, Betula spp., with a life history and feeding habits similar to EAB (Muilenburg and Herms 2012), have shown that rapid wound responses in hosts slows larval feeding (Muilenburg et al. 2013). These studies also suggest that a rapid wound response could help hosts encapsulate feeding larvae, thus leading to failed emergence and insect mortality (Miller et al. 1991; Muilenburg et al. 2013). The higher stem density and more rapid wound response in white fringetree could act as defense mechanisms against EAB. Rapid response to wounding equates to faster plant growth and may aid in defending plants, in lieu 
of metabolically expensive chemical defenses (Loehle 1988).

Chemical defenses may also play a role. Fraxinus spp. are rich in constitutive and induced phenolic defenses (Villari et al. 2015) which may affect insect development. While minor differences in chemical defenses are apparent in North American ash, they share a number of defensive compounds. With the exception of blue ash, all North American ash are classified as highly susceptible to EAB. To date there has been no research on defensive chemistry of white fringetree; clearly this warrants further investigation (Cipollini et al. 2011; Hill et al. 2012; Villari et al. 2015).

Parasitoids form the basis of the classical biological control program for EAB in North America (Herms and Mccullough 2014). Parasitoids require input from multiple sensory systems to locate their hosts, and they use various cues to locate cryptic hosts in situations where they would otherwise remain hidden (Vinson 1976; Vinson and Williams 1991). Such is the case for parasitoids locating host insects feeding within novel host plants. While olfactory cues may be involved, tactile and vibratory cues are likely the most significant for $T$. planipennisi locating EAB larvae feeding in ash (Ulyshen et al. 2011; Chen et al. 2015). Stem density is greater in fringetree relative to ash, which could affect tactile and vibratory properties of the plant; this in turn could present significant barriers for $T$. planipennisi host seeking behavior (Meyhöfer and Casas 1999). Tetrastichus planipennisi has successfully established and readily disperses from release points (Duan et al. 2013a, b), and shows promise in regulating EAB populations in regenerating forests following extensive EAB-induced ash mortality (Margulies et al. 2017). However, our findings suggest that the efficacy of $T$. planipennisi in EAB-infested white fringetree is questionable. Tetrastichus planipennisi appears unable to recognize EAB larvae within fringetree, suggesting that creation of enemy free space may be one mechanism by which utilization of white fringetree could facilitate EAB's range expansion into new hosts. This release from a key population regulator could allow EAB to further exploit this novel host, and further complicate future management efforts in North America. Clearly additional work is needed to determine how EAB's use of white fringetree might affect the efficacy of other classical biological control agents.
We confirm previous findings that white fringetree is a novel, yet suboptimal, host for EAB (Cipollini 2015; Cipollini and Rigsby 2015), and suggest potential mechanisms that may be at play. The relatively high survival of EAB on white fringetree in the laboratory ( $\sim 65 \%$, see Fig. 1a) suggests that it will not function as a dead-end host for EAB populations, but may provide an exploitable alternative host source. Given its ability to complete development from egg to adult, EAB has gained a reservoir host (Crowl et al. 2008) that may play a role in its invasion dynamics in North America by freeing it from dwindling ash hosts and availability of suitable host material. Our data suggest that by adopting and utilizing this novel host, EAB may reduce pressure from a notable natural enemy, further contributing to its invasibility. Our results confirm that $T$. planipennisi is not attracted solely to ash phloem odors (Ulyshen et al. 2011). Our data suggest that a combination of odor and visual cues may be important in host location for T. planipennisi. Interestingly, the combination of fringetree olfactory cues and visual stimuli that seemingly generate repellency of $T$. planipennisi to white fringetree support our observed lack of EAB parasitization within this novel host plant. These findings are puzzling and clearly warrant further investigation.

The invasion of North America by EAB is unprecedented in scope and magnitude (Herms and McCullough 2014), and continues to grow in complexity. Our study elucidates how expansion of its host range seemingly generates further enemy free space, contributing to EAB's invasiveness and altering previous management plans. Additionally, yet another oleacous plant, olive, Olea spp., has been added to an expanding host list for EAB (Cipollini et al. 2017) raising concerns about the far-reaching implications of this invasive pest. Furthermore, an Asian conspecific of EAB, A. smaragdifons Ganglbauer has reportedly established in eastern North America (Hoebeke et al. 2017). These confounding factors are likely to further contribute to the economic and ecological costs associated with the EAB invasion in North America and perhaps globally.

Acknowledgements The authors thank Ignazio Graziosi, Michelle Guo, Katherine Hagan, Jerry Hart, Mitch Hughes, Beth Kyre, Hannah Moore, Jim Nelson, Chad Niman, Felipe Pampolini, Samuel Rivers, for assistance with field and laboratory work. Lee Crawfort and Lexington-Fayette Urban County Government provided access to sampling sites. 
Parasitoids were kindly provided by the USDA APHIS PPQ Emerald Ash Borer Program, Brighton, MI. Eric Roemmele provided statistical support, and Kenneth Haynes and Daniel Potter provided feedback on an early version of the manuscript. We thank two anonymous reviewers who provided valuable input for improving the manuscript. This is publication number 18-08-37 of the Kentucky Agricultural Experiment Station paper and is published with the approval of the Director. This work is supported by the Kentucky Division of Forestry and the USDA Forest Service through a Landscape Scale Restoration Grant, and by McIntire Stennis Funds under 2351197000.

Open Access This article is distributed under the terms of the Creative Commons Attribution 4.0 International License (http:// creativecommons.org/licenses/by/4.0/), which permits unrestricted use, distribution, and reproduction in any medium, provided you give appropriate credit to the original author(s) and the source, provide a link to the Creative Commons license, and indicate if changes were made.

\section{References}

Abell KJ, Duan JJ, Bauer L, Lelito JP, Van Driesche RG (2012) The effect of bark thickness on host partitioning between Tetrastichus planipennisi (Hymen: Eulophidae) and Atanycolus spp. (Hymen: Braconidae), two parasitoids of emerald ash borer (Coleop: Buprestidae). Biol Control 63:320-325

Anulewicz CA, McCullough DG, Cappaert DC, Poland TM (2008) Host range of the emerald ash borer (Agrilus planipennis Fairmaire) (Coleoptera: Buprestidae) in North America: results of multiple choice field experiments. Plant Insect Interact 37:230-241

Bernays EA, Chapman RF (1994) Host-plant selection by phytophagous insects. Chapman \& Hall, NY, p 312

Burr SJ, McCullough DG (2014) Condition of green ash (Fraxinus pennsylvanica) overstory and regeneration at three stages of the emerald ash borer invasion wave. Can J For Res 44:768-776

Cappaert D, McCullough DG, Poland TM, Siegert NW (2005) Emerald ash borer in North America: a research and regulatory challenge. Am Entomol 51:152-165

Chen Y, Ulyshen MD, Poland TM (2015) Abundance of volatile organic compounds in white ash phloem and emerald ash borer larval frass does not attract Tetrastichus planipennisi in a Y-tube olfactometer. Insect Sci 23:712-719

Cipollini D (2015) White fringetree as a novel larval host for emerald ash borer. J Econ Entomol 108:370-375

Cipollini D, Rigsby CM (2015) Incidence of infestation and larval success of emerald ash borer (Agrilus planipennis) on white fringetree (Chionanthus virginicus), chinese fringetree (Chionanthus retusus), and devilwood (Osmanthus americanus). Environ Entomol 44:1375-1383

Cipollini D, Wang Q, Whitehill JG, Powell JR, Bonello P, Herms DA (2011) Distinguishing defensive characteristics in the phloem of ash species resistant and susceptible to emerald ash borer. J Chem Ecol 37:450-459
Cipollini D, Rigsby CM, Peterson DL (2017) Feeding and development of emerald ash borer (Coleoptera: Buprestidae) on cultivated olive, Olea europaea. J Econ Entomol 4:1935-1937

Crowl TA, Crist TO, Parmenter RR, Belovsky G, Lugo AE (2008) The spread of invasive species and infectious disease as drivers of ecosystem change. Front Ecol Environ 6:238-246

Davidson W, Rieske LK (2015) Native parasitoid response to emerald ash borer (Coleoptera: Buprestidae) and ash decline in recently invaded forests of the central United States. Ann Entomol Soc Am 108:777-784

Davidson W, Rieske LK (2016) Establishment of classical biological control targeting emerald ash borer is facilitated by use of insecticides with little effect on native arthropod communities. Biol Control 101:78-86

Davis MA, Pelsor M (2001) Experimental support for a resource-based mechanistic model of invisibility. Ecol Lett $4: 421-428$

Davis MB, Woods KD, Webb SL, Futyma RP (1986) Dispersal versus climate: expansion of Fagus and Tsuga into the Upper Great Lakes regions. Vegetation 67:93-103

Davis MA, Grime JP, Thompson K (2000) Fluctuating resources in plant communities: a general theory of invasiblity. J Ecol 88:528-536

Davis MA, Bier L, Busheslle E, Diegel C, Johnson A, Kujala B (2005) Non-indigenous grasses impeded woody succession. Plant Ecol 178:249-264

Drake JM (2003) The paradox of the parasites: implications for biological invasion. Proc Biol Sci 270:S133-S135

Duan JJ, Fuester RW, Wildonger J, Taylor PB, Barth S, Spichiger SE (2009) Parasitoids attacking the emerald ash borer (Coleoptera: Buprestidae) in Western Pennsylvania. Fla Entomol 92:588-592

Duan JJ, Oppel CB, Ulyshen MD, Bauer LS, Lelito J (2011) Biology and life history of Tetrastichus planipennisi (Hymenoptera: Eulphidae), a larval endoparasitiod of the emerald ash borer (Coleoptera: Buprestidae). Fla Entomol 94:933-940

Duan JJ, Bauer LS, Abell KJ, Van Driesche R (2012) Population responses of hymenopteran parasitoids to the emerald ash borer (Coleoptera: Buprestidae) in recently invaded areas in north central United States. Biocontrol 57:199-209

Duan JJ, Bauer KJ, Abell KJ, Lelito JP, Van Driesche R (2013a) Establishment and abundance of Tetrastichus planipennisi (Hymenoptera: Eulophidae) in Michigan: potential for success in classical biological control of invasive emerald ash borer (Coleoptera: Buprestidae). J Econ Entomol 106:1145-1154

Duan JJ, Taylor P, Watt T, Larson K, Lelito J (2013b) Effects of ambient temperature on egg and larval development of the invasive emerald ash borer (Coleoptera: Buprestidae): implications for laboratory rearing. J Econ Entomol 106:2101-2108

Duan JJ, Abell KJ, Bauer LS, Gould J, Van Driesche RG (2014) Natural enemies implicated in the regulation of an invasive pest: a life table analysis of the population dynamics of the emerald ash borer. Agric For Entomol 16:406-416

Duan JJ, Bauer LS, Abell KJ, Ulyshen MD, Van Driesche RG (2015) Population dynamics of an invasive forest insect and associated natural enemies in the aftermath of 
invasion: implications for biological control. J Appl Ecol 52:1246-1254

Dunn JP, Potter DA, Kimmerer TW (1990) Carbohydrate reserves, radial growth, and mechanisms of resistance of oak trees to phloem-boring insects. Oecologia 83:458-468

Elton CS (1958) The ecology of invasions by animals and plants. Methuen, London

Flower C, Knight K, Gonzalez-Meler M (2013) Impacts of the emerald ash borer (Agrilus planipennis Fairmaire) induced ash (Fraxinus spp.) mortality on forest carbon cycling and successional dynamics in the eastern United States. Biol Invasions 15:931-944

Gandhi K, Herms D (2010) North American arthropods at risk due to widespread Fraxinus mortality caused by the alien emerald ash borer. Biol Invasions 12:1839-1846

Gratton C, Welter SC (1999) Does "enemy-free space" exist? Experimental host shifts of an herbivorous fly. Ecology 80:773-785

Graziosi I, Rieske LK (2013) Response of Torymus sinensis, a parasitoid of the gallforming Dryocosmus kuriphilus, to olfactory and visual cues. Biol Control 67:137-142

Graziosi I, Rieske LK (2017) The battle plan: defining a strategy to manage the emerald ash borer in Kentucky forests. Ky Woodl Mag 11:21-22

Haack RA, Jendak E, Houping L, Marchant KR, Petrice TR, Poland TM, Ye H (2002) The emerald ash borer: a new exotic pest in north America. Newsl Mich Entomol Soc 47:1-5

Herms DA, McCullough DG (2014) Emerald ash borer invasion of North America: history, biology, ecology, impacts, and management. Annu Rev Entomol 59:13-30

Hill AL, Whitehill JG, Opiyo SO, Phelan PL, Bonello P (2012) Nutritional tributes of ash (Fraxinus spp.) outer bark and phloem and their relationships to resistance against the emerald ash borer. Tree Physiol 32:1522-1532

Hoebeke ER, Jandek E, Zablotny JE, Rieder R, Yoo R, Grebennikov VV, Ren L (2017) First North American records of the eastasian metallic wood-boring beetle Agrilus smaragdifrons Ganglbauer (Coleoptera: Buprestidae: Agrilinae). A specialist on tree of heaven (Ailanthus altissima, Simaroubaceae). Proc Entomol Soc Wash 119:408-422

Hunter MD, Price PW (1992) Playing chutes and ladders: heterogeneity and the relative roles of bottom-up and topdown forces in natural communities. Ecology 73:724-732

Huston MA (1997) Hidden treatments in ecological experiments: re-evaluating the ecosystem function of biodiversity. Oecologia 108:449-460

Huston MA, DeAngelis DL (1994) Competition and coexistence: the effects of resource transport and supply rates. Am Nat 144:954-977

Jeffries MJ, Lawton JH (1984) Enemy free space and the structure of ecological communities. Biol J Linn Soc 23:269-286

Jennings DE, Duan JJ, Bean D, Gould JR, Rice KA, Shrewsbury PM (2016) Monitoring the establishment and abundance of introduced parasitoids of emerald ash borer larvae in Maryland, USA. Biol Control 101:138-144

Klooster WS, Herms DA, Knight KS, Herms CP, McCullough DG, Smith A, Cardina J (2014) Ash (Fraxinus spp.) mortality, regeneration, and seed bank dynamics in mixed hardwood forests following invasion by emerald ash borer (Agrilus planipennis). Biol Invasions 16:859-873

Levin-Nielsen A, Rieske LK (2015) Evaluating short term simulations of a forest stand invaded by emerald ash borer. iFor Biogeosci For 8:19-24

Lindell CA, McCullough DG, Cappaert D, Apostolou NM, Roth MB (2008) Factors influencing woodpecker predation on the emerald ash borer. Am Midl Nat 159:434-444

Liu H, Bauer LS, Gao R, Zhao T, Petrice TR, Haack RA (2003) Exploratory survey for the emerald ash borer, Agrilus planipennis (Coleoptera: Buprestidae), and its natural enemies in China. Gt Lakes Entomol 36:191-204

Loehle C (1988) Tree life history strategies: the role of defenses. Can J For Res 18:209-222

Looney CE, D'Amato AW, Palik BJ, Slesak RA, Slater MA (2017) The response of Fraxinus nigra forest ground-layer vegetation to emulated emerald ash borer mortality and management strategies in northern Minnesota, USA. For Ecol Manag 389:352-363

Lyons DB, de Groot P, Jones GC, Scharback R (2009) Host selection by Agrilus planipennis (Coleptera: Buprestidae): inferences from sticky-band trapping. Can Entomol 141:40-52

Margulies E, Bauer L, Ibanez I (2017) Buying time: preliminary assessment of biocontrol in the recovery of native forest vegetation in the aftermath of the invasive emerald ash borer. Forests 8:369

Mattson WJ (1980) Herbivory in relation to plant nitrogen content. Annu Rev Ecol Syst 11:119-161

Meier ES, Kienast F, Pearman PB, Svenning JC, Thuiller W, Araújo MB, Guisan A, Zimmermann NE (2010) Biotic and abiotic variables show little redundancy in explaining tree species distributions. Ecography 33:1038-1048

Meyhöfer R, Casas J (1999) Vibratory stimuli in host location by parasitic wasps. J Insect Physiol 45:967-971

Miller RO, Bloese PD, Hanover JW, Haack RA (1991) Paper birch and European white birch vary in growth and resistance to bronze birch borer. J Ame Soc Hortic Sci 116:580-584

Missouri Botanical Garden (2017) Chionanthus virginicus http://www.missouribotanicalgarden.org/PlantFinder/ PlantFinderDetails.aspx ?kempercode $=\mathrm{c} 120$. Accessed 19 Jan 2017

Muilenburg VL, Herms DA (2012) A review of bronze birch borer (Coleoptera: Buprestidae) life history, ecology, and management. Environ Entomol 41:1372-1385

Muilenburg V, Phelan PL, Bonello P, Loess PF, Herms DA (2013) Characterization of wound responses of stems of paper birch (Betula papyrifera) and European white birch (Betula pendula). Trees 27:851-863

Murphy S (2004) Enemy-free space maintains swallowtail butterfly host shift. Proc Natl Acad Sci 101:18048-18052

Perry KI, Herms DA (2016) Response of the forest floor invertebrate community to canopy gap formation caused by early stages of emerald ash borer-induced mortality. For Ecol Manag 375:259-267

Peterson DL, Duan JJ, Yaninek JS, Ginzel MD, Sadof CS (2015) Growth of larval Agrilus planipennis (Coleoptera: Buprestidae) and fitness of Tetrastichus planipennisi (Hymenoptera: Eulophidae) in blue ash (Fraxinus 
quadrangulata) and green ash ( $F$. pennsylvanica). Environ Entomol 44:1512-1521

Rasband WS (1997-2016) ImageJ, U. S. National Institutes of Health, Bethesda, Maryland, USA. https://imagej.nih.gov/ ij/. Accessed Jan 2018

Rebek EJ, Herms DA, Smitley DR (2008) Interspecific variation in resistance to emerald ash borer (Coleoptera: Buprestidae) among North American and Asian ash (Fraxinus spp.). Environ Entomol 37:242-246

Richardson DM, Pyšek P (2006) Merging the concepts of species invasiveness and community invisibility. Plant Invasions 30:409-431

Ruiz GM, Rawlings TK, Dobbs FC, Drake LK, Mullady T, Huq A, Colwell RR (2000) Global spread of microorganisms by ships. Nature 408:49

Savage MB, Rieske LK (2018) Coleopteran communities associated with forests invaded by emerald ash borer. Forests 9:69

Sax DF, Stachowicz JJ, Brown JH, Bruno JF, Dawson MN, Gaines SD, Grosberg RK, Hastings A, Holt RD, Mayfield MM, O'Connor MI, Rice WR (2007) Ecological and evolutionary insights from species invasions. Trends Ecol Evol 22:465-471

Siegert NW, McCullough DG, Liebhold AM, Telewski FW (2014) Dendrochronological reconstruction of the epicenter and eary spread of emerald ash borer in North America. Divers Distrib 20:847-858

Smitley DR, Doccola DR, Cox DL (2010) Multiple-year protection of ash trees from emerald ash borer with a single trunk injection of emamectin benzoate, and single-year protection with an imidacloprid basal drench. J Arboric 36:206

Spei BA, Kashian DM (2017) Potential for the persistence of blue ash in the presence of emerald ash borer in southeastern Michigan. For Ecol Manag 392:137-143

Stamp N (2001) Enemy-free space via host plant chemistry and dispersion: assessing the influence of tri-trophic interactions. Oecologia 128:153-163

Strong DR, Simberloff D, Abele LG, Thistle AB (1984) Ecological communities: conceptual issues and the evidence. Princeton University Press, Princton, p 630

Tanis SR, McCullough DG (2012) Differential persistence of blue ash and white ash following emerald ash borer invasion. Can J For Res 42:1542-1550
Thiemann D, Lopez V, Ray AM, Cipollini D (2016) The history of attack and success of emerald ash borer (Coleoptera: Buprestidae) on white fringetree in Southwestern Ohio. Environ Entomol 45:961-966

Ulyshen MD, Mankin RW, Chen Y, Duan JJ, Poland TM, Bauer LS (2011) Role of emerald ash borer (Coleoptera: Buprestidae) larval vibrations in host-quality assessment by Tetrastichus planipennisi (Hymenoptera: Eulophidae). J Econ Entomol 104:81-86

USDA APHIS MAP (2018) Emerald ash borer. http://www. emeraldashborer.info/documents/MultiState_EABpos.pdf. Accessed 13 Sept 2018

Verhoef HA, Morin PJ (2010) Community ecology: processes, models and applications. Oxford University Press, Oxford, p 247

Villari C, Herms DA, Whitehill JG, Cipollini D, Bonello P (2015) Progress and gaps in understanding mechanisms of ash tree resistance to emerald ash borer, a model for wood boring insects that kill angiosperms. New Phytol 209:63-79

Vinson SB (1976) Host selection by insect parasitoids. Annu Rev Entomol 21:109-133

Vinson SB, Williams HJ (1991) Host selection behavior of Campoletis sonorensis: a model system. Biol Control 1:107-117

Wang X, Yang Z, Liu G, Liu E (2005) Larval instars and stadia of Agrilus planipennis (Coleoptera:Buprestidae). Sci Silvae Sin 41:97-102

Whitehill J, Opiyo S, Koch J, Herms D, Cipollini D, Bonello P (2012) Interspecific comparison of constitutive ash phloem phenolic chemistry reveals compounds unique to manchurian ash, a species resistant to emerald ash borer. J Chem Ecol 38:499-511

Wisz MS, Pottier J, Kissling WD, Pellissier L, Lenoir J, Damgaard CF, Dormann CF, Forchhammer MC, Grytnes JA, Guisan A, Heikkinen RK, Høye TT, Kühn I, Luoto M, Maiorano L, Nilsson MC, Normand S, Öckinger E, Schmidt NM, Termansen M, Timmermann A, Wardle DA, Aastrup P, Svenning JC (2013) The role of biotic interactions in shaping distributions and realized assemblages of species: implications for species distribution modeling. Biol Rev 88:15-30 